\title{
The effects of internal and external resource management on logistics performance
}

\author{
Mohamed Salih Yousif Alia ${ }^{{ }^{*}}$ and Emad Aldeen Essa Eshag Abou ${ }^{\text {b }}$
}

${ }^{a}$ Faculty Member, Department of Business Administration, College of Science and Humanities Studies, Prince Sattam Bin Abdul Aziz University, Al-Aflaj, Saudi Arabia

${ }^{b}$ Department of Business Administration, College of Business Studies, Sudan University of Science and Technology, Khartoum, Sudan

\section{H R O N I C L E}

\section{A B S T R A C T}

\section{Article history:}

Received March 9, 2021

Received in revised format May 6, 2021

Accepted June 172021

Available online

July 252021

Keywords:

Extended resources based view

Logistics information technology

Logistic performance

Suppliers' resources

Top management beliefs

\begin{abstract}
This empirical study aims to elucidate the effects of logistics information technology (LIT), top management beliefs (TMBs), and suppliers' resources selection (SRS) on logistics performance. The extended resources-based view (ERBV) supports the development of the proposed relationships in the study model, based on previous studies measures. Structural equation modeling (SPSS and AMOS v 25) was utilized to test the validity of the model and proposed hypotheses. Based on responses from 229 surveyed companies in Sudan's food and beverages sector, this study' findings showed that the LIT, TMBs, and SRS influence logistic cost performance (LCP) and logistic delivery performance directly. Additionally, it showed that company size could moderate the relationship between LCP and LIT, TMBs, and SRS. This study provides several theoretical and practical implications by evaluating the ability of LIT, SRS, and TMBs to improve delivery and cost performance.
\end{abstract}

(C) 2021 Growing Science Ltd. All rights reserved.

\section{Introduction}

Logistics performance can be viewed as a subset of the broader organizational output concept (Duong \& Paché, 2016). To improve delivery performance and reduce performance cost, firms need to manage logistics information technology (LIT), top management beliefs (TMBs), and suppliers' resources selection (SRS). Improving logistics performance depends on the availability of internal resources and outside excellent partners' resources that offer competitive advantages to firms. The competitive advantage of a firm does not stem solely from its internal resources, but also from opportunities seized in its external environment's resources. In this study, logistics performance is gauged by costs and delivery.

Logistics cost refers to the ability to incur the lowest possible total logistics cost through efficient operations, technology, and scale economies (Zhao et al., 2001). Vinholis et al. (2014) referred to these as transaction costs. Stewart (1995) indicated that two of the four key areas that organizations need to excel at are delivery performance and logistics costs. In supply chain management, cost performance reduction and improving quality delivery levels are imperative for firms' performance improvement strategies that include the cost of upstream (supplier) and downstream (customer) services in a chain.

Delivery performance entails providing services in a responsive and attentive manner (Lages et al., 2020); it reflects the demand-responsiveness logistics capabilities. Excellence in delivery performance is considered as one of the means of a firms' success. Further, handling customers' demands, storing goods, and fast deliveries are the main challenges that manufacturers face. Delivery performance entails delivery in high demand periods, faultless delivery, in-time delivery, and delivery according to the timetable, compared to a firm's major competitors.

* Corresponding author

E-mail address: my.ali@psau.edu.sa (M. S. Y. Ali)

(C) 2021 Growing Science Ltd. All rights reserved.

doi: $10.5267 /$ j.uscm.2021.7.011 
Many authors have argued that information technology (IT) can potentially affect a full range of strategic and industry variables, such as cost positions, economies of scale, and power relations with buyers and suppliers, which provides a cutting edge and sustainable competitive advantage to a firm (Eisenhardt \& Martin, 2000; Benjamin et al., 1984; Wiseman, 1985; McFarland, 1984; Porter, 1985; Clemons, 1986). IT motivates firms to integrate the most functional transactions, which promotes their internal operational efficiency and ties up business relations and information standardization with their supply chain partners, when they perceive the potential shared value and the need to collaborate. IT can be potentially applied at all stages and areas of industrial supply chains, offering significant opportunities for firms (Li et al., 2016). LIT refers to any electronic communication technology for information that is related to a firm's logistic performance.

According to many authors, the top management's values, beliefs, and actions are critical in shaping organizational behavior and implementing a firm's strategies and performance decisions (Yuana et al., 2020; Lai et al., 2016; Villena et al., 2009; Collins et al., 2008; Hambrick, 2007; Shrivastava, 1983). TMBs refer to the mental image held by top management regarding its strategic actions' potential benefit to the firm (Wei et al., 2020). They facilitate the sharing and interacting of logistics practices' resources and stages.

Suppliers' resources are key for customer service quality, which entices management to rely on them. Numerous authors have shown that integrating firm operations with suppliers' resources positively relates to firm performance (Mitrega, Forkmann, Ramos, \& Henneberg 2012; Boon-itt \& Wong, 2011; Flynn et al., 2010; Singh \& Power, 2009; Swink et al., 2007; Rosenzweig et al., 2003; Gadde \& Snehota, 2000). Suppliers' resources refer to any firm that supplies inputs to manufacturing firms, and the literature has suggested a set of criteria for effective SRS (see, Adebanjo, Ojadi, Laosirihongthong \& Tickle 2013; Ordoobadi, 2009; Ha and Krishnan, 2008). Previous studies have provided empirical evidence indicating that key partner relationships should be considered as sources of competitive advantage (Wisner, 2003) and a platform for value differentiation (Ulaga \& Eggert, 2006) in the supply chain context.

Extended resources-based view (ERBV) posits that a focal firm can use external and internal resources for competitive advantages (Lavie, 2006). Fawcett and Magnan (2004) argued that by extending the resource-based view logic, firms strive for greater supply chain collaboration to leverage the resources and knowledge of their suppliers and customers. Many authors have studied the ERBV concept to gain competitive advantage using inter-firm resources (Xu, Huo and Sun 2014; Son, Lee, Lee, and Chang 2014; Jia and Lamming, 2013; Lavie, 2006). To develop the integrated conceptual model, this study used ERBV to demonstrate that linking a firm's internal resources with other firms' resources produces competitive advantages.

Currently, increased competition and market turbulence force food manufacturers to search for a promising solution to reduce performance cost and delivery performance. The different types of resources used by firms have not been analyzed systematically (Warnier, Weppe and Lecocq 2013). In food service businesses, the growth and pervasiveness of dining out have an important role toward more sustainable and healthy food systems (Takacs and Borrion, 2020). Castro1 and Jaimes (2017) found that investigations on supply chains of perishable foods are scarce. Fresh food products, fast delivery, safety, and food quality are challenges faced by firms. To create value, firms must acquire, accumulate, combine, and exploit resources; however, little is known about how managers transform these resources to create value (Sirmon, Hitt and Ireland 2007). The problems firms face include the difficulty to fulfill the customers' needs from a single supplier and to fulfill the firm's needs from a single supplier (Park, Shin, Chang, and Park 2010). Therefore, firms encourage suppliers' involvement when seeking ways to shorten new product development time, improve quality, reduce cost, and release new products smoothly and to develop their capabilities and maintain suppliers resources. Currently, no studies have researched the impact of firms' LIT, TMBs, and SRS on logistics performance that is moderated by company's size. Based on the overhead background, this study's first research question is as follows: What are the effects of LIT, TMBs, and SRS on logistics performance?

Given the role of company size in logistics performance, it plays significant roles in organizational performances (Oliveira and Martins, 2011). Firm size is a significant moderator of firm performance in resource based view (RBV) studies (Raguseo, Vitari, and Pigni 2020). Utilizing company size provides considerable insight into top management activities, LIT processes, and SRS. This study's second research question is as follows: Does company size moderate the impacts of TMBs, LIT, and SRS on logistic cost performance (LCP) and logistic delivery performance (LDP)?

This study's objectives include achieving cost effectiveness, efficiency, and improvement of delivery performance in logistics. As such, it surveyed Sudan's food and beverage sector managers to investigate TMBs, LIT, and SRS in logistics performance, following the need, and lack of literature, to better understand the drivers of such relationships in manufacturing industries that should be managed and converted into resources to generate value for cost competitive, sustainability, and customers' satisfaction.

\section{Extended resource-based view support for the study's model}

From the resource-based perspective, firms can draw on a wide array of external resources, through both market-mediated transactions and various kinds of resource exchanges and leverage relations that link firms in value-chains (Mathews, 2000). Arya and Lin (2007) revealed that supporting internal with external resources allows some organizations to increase their performance capabilities. External resources can provide focal firms with strategic opportunities that pose fewer risks and incur less cost (Reuer \& Koza, 2000). Thus, the dyadic focus on both internal and external market resources was more 
beneficial than the individual focus on one resource to perfect firm performance, when these resources converge based on importance to the organizations.

According to Mathews (2000), resources can be specialized and bundled together in highly distinctive configurations to lend firms special competitive advantages. Thus, combining internal and external resources extracts greater value than when the resources are used individually. Firm value-creation depends on how such a firm combines internal resources within it and external resources from other firms. Based on this extended resource based view, both internal and external resources are used for bigger competitive dynamics, compared to those that depend solely on internal resources.

Barney (2001) defined resources as tangible and intangible assets that organizations use to choose and implement strategies. Tangible and intangible assets can be considered as explicit and tacit resources, respectively. Explicit resources are easily acquired (LIT, SRS), while tacit resources are personal and difficult to acquire (TMBs). Firms perform better after linking tacit and explicit resources with external resources.

We consider ERBV as another probable theory that can work properly in conjunction with influential theories that analyze supply chain parties' relationships to economize on costs and improve delivery performance. This theory is a smart bridge that links internal and external resources to address a firm's environmental assets management. ERBV provides a wide representation of resources used by firms to enhance market achievement value, which encourages the empirical investigation of important external resources.

ERBV extends the theoretical boundary of RBV and emphasizes that some resources may lie beyond a firm's boundary (Son et al., 2014; Yang et al., 2019). Therefore, competitive advantage is derived from both internal and external assets. This study involves suppliers' resources as necessary external resources that require strategic selection from management. These can be individual, multiple, or a combination of suppliers, depending on the industry types, and their selection may require more than one approach. Therefore, firms can efficiently obtain competitive advantage by successfully selecting external resources, such as supplier's offers and capability to manage them, and the firms' internal resources, such as LIT and TMBs.

\section{Theoretical background and hypotheses}

IT can support organizational efforts to generate new and better business value (Raguseo et al., 2020). IT has significant influence on collaborative planning between firms; and their partners (Lai et al., 2016). Different LIT tools that firms use generate transparency and quickly support demand activities of the logistics workflow in a simple systematic manner by providing quick responses to networks of supply chain partners. IT helps to automatically forward logistics information flow and reverse real-and near-time information (Winkelhaus \& Grosse, 2020). IT exchanges reliable information within work networks and facilitates quick information transmission and complete coordination. It helps to innovate and manage practices such as customer service quality, production cost reduction, and obsolescence of goods. Electronic communication and data interchange, as examples of IT, are used to speed up transactions.

Therefore, IT studies that adopt RBV seek to conceptually explain whether IT resources contribute to a firm's competitive advantage and how a firm utilizes its IT assets to achieve efficient performance (Wade \& Hulland, 2004). An efficiently functioning IT system is important for running logistics operations effectively (Bag et al., 2020); LIT is used to attain integration between internal functions and key suppliers and customers. In addition, IT is an important element for halal logistics performance (Masudin et al., 2018). Logistics research has consistently shown that competence in managing IT is critical to logistics performance (Zhao et al., 2001). Benjamin and Terry (2012) found that adopting logistic IT enhances the adopting firm's effectiveness, efficiency, and resilience. Firms face customers who require goods with a very short lead-time (Kritchanchai et al., 2018). Well-designed LIT processes enable firms to speed up logistics information sharing between the supply chain parties, exchange reliable and accurate information, control information expenditures, and complete full coordination. IT supports order tracking and product specification by sharing demand and orders processing information intensity with supply chain partners.

TMBs steer managers and business units toward opportunities leading to the targeted organizational status (Yang \& Lee, 2016; Fang et al., 2014). These beliefs affect the management's commitment to desired actions and practices. When top management finds qualified suppliers' stimuli, such as resources, they decide to share business, reduce cost, and achieve speedy delivery performance. Top managers develop their belief structures in analyzing and responding to environmental factors and use these beliefs to guide administrative behaviors or actions (Lee et al., 2014; Dai et al., 2014; Liang et al., 2007). Grimm et al. (2014) noted that top management support is among the important internal critical factors for sustainable practices in a supply chain. Manufacturers and their corresponding supply chain partners strive to co-create increased customer value through collaborations (Lee and Dinwoodie, 2016); TMBs drive these collaborations. Positive TMBs generate out value for performance decisions because these beliefs control any decision-making processes.

Logistics performance encompasses several service evaluation metrics that relate to multiple parties, such as customers, suppliers, and service providers (Ouafae \& Laila 2019). Sourcing for appropriate suppliers is vital to securing production inventory and avoiding increased cost. Management identifies the suppliers and supplier groups to be targeted as part of a firm's business mission (Lambert \& Schwieterman, 2012). The supplier becomes more involved in the quality control processes (Van Weele, 2009), enabling firms to gain more supply chain benefits and plan and execute adequate operations 
(Richey et al., 2009). Conversely, firms can improve suppliers' capabilities, provide staff training, and develop their performance to subtend the required needs.

For manufacturers, the most appropriate suppliers effectively deliver competitively priced, high quality products and services to their final customers, according to their demand (Choy et al., 2003). Selecting suitable suppliers' resources enhances firm efficiency and maximizes benefits for both. Buyers and suppliers who share resources can generate competitive advantages and enhance relationships value between firms (Cheung et al., 2010). Vonderembse and Tracey (1999) concluded that involving suppliers has a positive effect on a buyer's performance. Further, suppliers reduce managerial supervision (Tuo et al., 2019). A good supplier selection process efficiently influences manufacturing performance because a supplier's operations directly affect a buyer's performance (Gimenez and Tachizawa 2012; Park et al., 2010; Ting \& Cho, 2008; Jabbour \& Jabbour, 2009; Bhutta \& Huq 2002), and is critical for building a dynamic collaboration capability that achieves differential performance (Liao et al., 2010). Suppliers' resource selection helps to ensure timely delivery, responsiveness, flexibility, and early forecasting analytics. The food producer-supplier interaction is traditionally important creating a firm's reputation for both business-to-business firms. Managing suppliers' relationships play an important role in cost reduction and performance optimization in industrial enterprises (Mettler and Rohner, 2009). Logistics performance should indicate the organization's ability to deliver goods and services when required at acceptable cost in the quantities required by customers (Green et al., 2008). Based on these discussions, we formulate the following two hypotheses:

$\mathbf{H}_{1}$ : (a) Firm's LIT, (b) TMBs, and (c) SRS are positively linked with the LCP.

H2: (a) Firm's LIT, (b) TMBs, and (c) SRS are positively linked with the LDP.

Company size is one of the organizational contingencies that influences performance measurements practices (Chenhall, 2003), and supply chain management practices (Li et al., 2006). It determines executives' decision-making discretion (Hambrick \& Finkelstein, 1987). Michaelis et al. (2015) found that the company size moderates the positive relationship between prior company performance and chief executive officer charisma attributions in large companies. Buonanno et al. (2005) found that company size is a significant predictor of enterprise resource planning adoption. The implementation of IT is affected by company size, favoring large firms over small and medium-sized enterprises (SMEs) (Müller et al., 2018); therefore, the third hypothesis is proposed.

$\mathbf{H}_{3}$ : Company size moderates the effects of (H3a) LIT, (H3b) TMBc, and (H3c) SRS on (1) LCP and (2) LDP.

\section{Methodology}

ERBV is used to support this study's conceptual framework. This study is based on a self-administering questionnaire survey in Sudan's food and beverages industry. The questionnaires are addressed to all types of firms that industry and include two parts of questions. The first part contains surveyed firms' demographic characteristics and the second one comprises three independent variables (LIT, TMBs, and SRS) and two dependent variables (LDP and LCP). This second part of the questionnaire was based on a seven-point Likert scale structured from (1) completely disagree to (7) completely agree. The Arabic language used to explain the questionnaire could be easily understood by potential respondents. Two bilingual academic experts translated the questionnaire, first from Arabic to English and then from English to Arabic, to increase its perceived meaning. Additionally, 15 business administration master students in Sudan University of Sciences and Technology conducted the pretest to secure the reliability and validity of the measurements' statements and to decrease the loss of meanings. Since the Industrial Ministry of Khartoum State, which has the biggest number of industrial companies in Sudan, had not updated the information of the surveyed list of firms, we did not define our study population; thus, we depended on convenience sampling surveys for a whole month of December, 2020. To stimulate greater commitment and collaboration, a pre-notified telephone call was made to the target firms' management to get their consent to participate in the survey voluntarily. Out of 400 firms, 250 agreed to participate; each firm provided an individual experienced and knowledgeable in the logistic field. The sample size is suitable according to Hair et al., (2010), who noted that for structural equation modeling (SEM) with five or fewer constructs, each construct with three or more items can be adequately estimated using as small as 100-150 samples. Thus our sample size is suitable for the SEM analysis. The Public Relations and Human Resources departments in each company received and distributed the questionnaires to the target respondents in the logistic field. Descriptive statistics, unengaged responses check, different reliability tests, sampling adequacy, Bartlett's sphericity test, SEM, regression analysis methods, among others, were used to test the internal consistency to ensure the goodness of fit and reliability of each construct. The (SPSS \& AMOS v 25) was used to analyze the data collected.

\subsection{Measurements}

This study's scale was developed following the criterion procedures in previous studies and literature recommendations. Study items used by Min and Mentzer (2004), Yuana et al. (2020), Wei et al. (2020) and Gopalakrishna-Remani et al. (2019) measure TMBs. Those by Zhao et al. (2001) measured LIT. Ang's and Cummings (1997), Miranda and Kim (2006), Mitrega et al. (2012) and Yuana et al. (2020) redesigned their scales to measure SRS. Han, Lee, and Seo (2008) and Huo et al. (2008) employed their study items to measure LCP. Boon-Itt and Wong (2011), Hsiao, Kemp, Van der Vorst and Omta (2010), and Doering, De Jong \& Suresh (2019) measurements were used to assess LDP. The total items used in this study's instrument were 16. Table 1 presents all the study's items of measurements. 
Table 1

EFA Analysis, KMO and Bartlett's Test

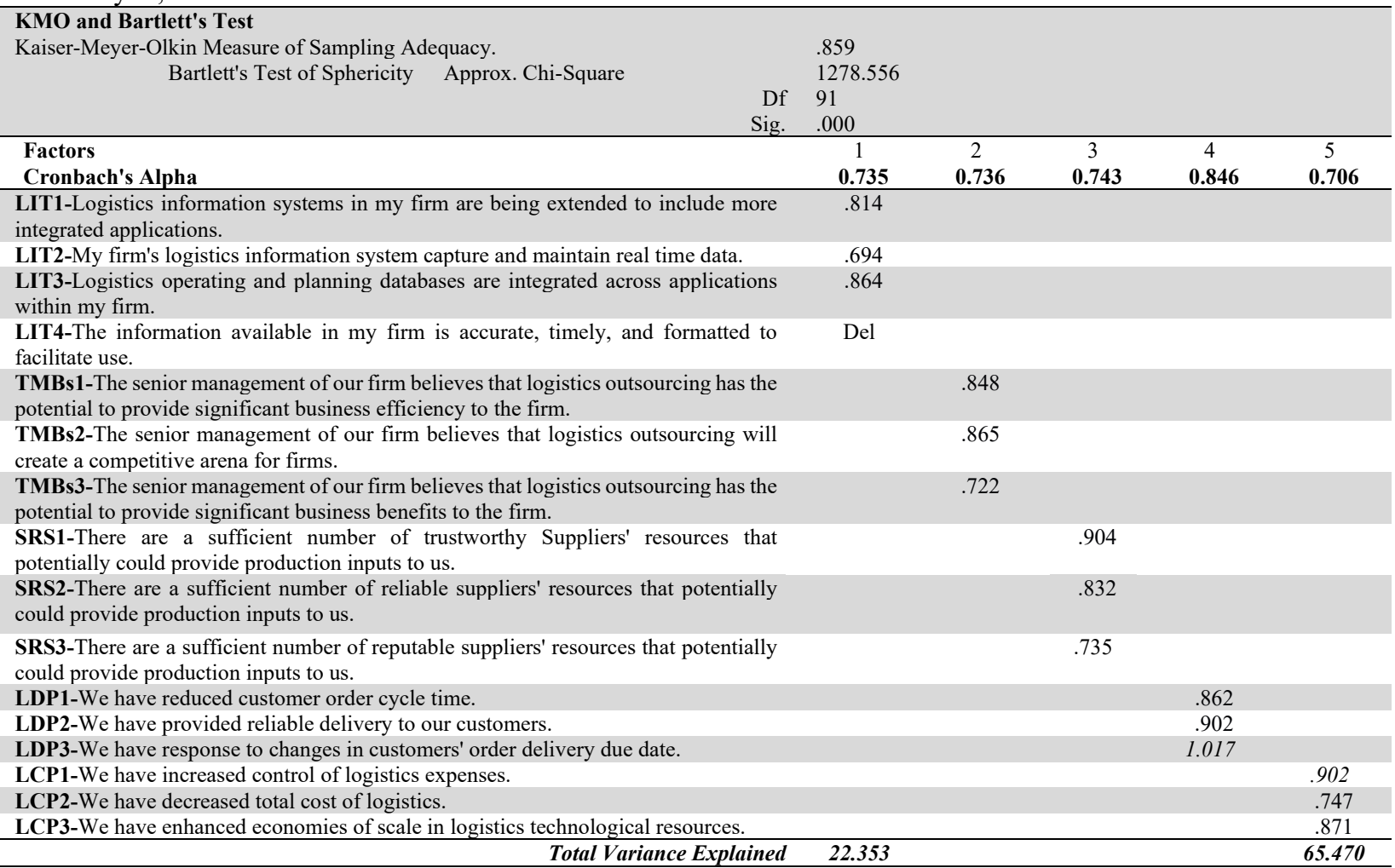

\subsection{Nonresponse Bias (NRB) and Common method bias (CMB) tests}

To check NRB we used Armstrong and Overton's (1977) guidelines. The first two weeks wave responses were considered as earlier responses and compared with the second two weeks wave responses used as later responses. The t-statistics show no statistically significant differences between the two waves noticed. Thus, the NRB was not a main concern in our study's data.

Several guidelines were used to test CMB. First, regarding the structure of our study instrument, an introductory paragraph explains each study variable before the respondents reply to the questions, helping them understand the questions clearly. Further, the wording of the questionnaire items was neutral, and confidentiality of the responses data was assured. These steps reduced the probability of CMB occurrence. Second, to prevent our study measurement from CMB, Podsakoff's, Mackenzie, Lee, and Podsakoff (2003) procedures for a single informant response were used. The exploratory factor analysis (EFA) results on all 16 items of our model showed that the total variance explained is $(65.47 \%)$ and first factor variance explained is $(22.35 \%)$, which did not constitute half or more than the total variance of the other factors, providing confidence that CMB was not a risk issue in this study's data.

After several visits and reminder calls to surveyed firms, we collected 241 responses, with 229 valid questionnaires from each firm's senior logistics manager or individuals in similar positions (response rate $=96 \%$ ). Clear terms regarding the timeframe for data collection, and how the participants could return the survey forms, were expressed in a cover letter attached with the questionnaire.

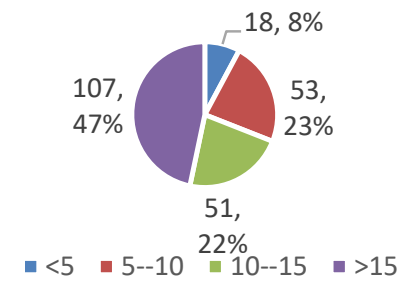

Company Years of Experience

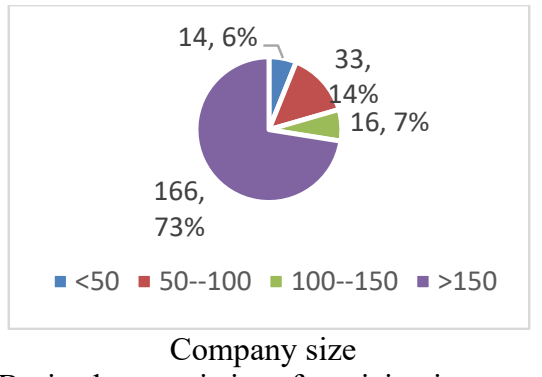

Company size

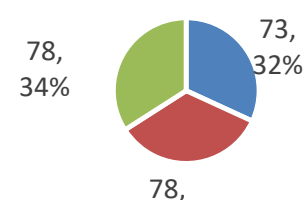

- Public - Private -Shareholder

Ownership of the Companies

Fig. 1. Basic characteristics of participating companies

Participating companies with 15 years of experience and more, 5-10 years, 10-15 years, and less than 5 years represent $46.7 \%, 23.1 \%, 22.3 \%$, and $7.9 \%$ of the sample, respectively. Participating companies with more than 150 employees, $50-100$ 
employees, 100-150 employees, and less than 50 employees were $72.5 \%, 14.4 \%, 7 . \%$, and 6.1\%, respectively. The three participating company types (public, private and shareholders) had almost equal sample representations, with each representing approximately one-third of the samples. Fig. 1 represents the basic characteristics of the participating companies.

\section{Data analysis and results}

\subsection{Exploratory factor analysis (EFA)}

The Cronbach's alpha coefficient values of all the extracted factors showed that Cronbach's alpha for the original five variables exceeded the suggested threshold of 0.7 (Hair et al., 2010). Bartlett's test of sphericity was used to confirm the relevance of the factor analysis, which was evaluated by examining the correlation matrix of the collected data (Hair, Black, Babin, Anderson, \& Tatham 2006). Similarly, sampling adequacy was calculated using Kaiser-Meyer-Olkin (KMO) statistics. Bartlett's test of sphericity score and the KMO values yielded .859 (above the recommended minimum level of 0.60 ). Thus, Bartlettes $s$ test of Sphericity is significant $(\mathrm{p}<.01)$, the items are appropriate for EFA analysis, and the sample size is adequate for SEM (Gaskin, 2012; Kenny and McCoach, 2003). EFA was conducted through a structured order, using maximum likelihood on 16 items used to measure this study's variables. One item was deleted owing to less factor loading than the minimum requirement of 0.50 of the average variance extracted (AVE) and cross loading in the first run test. Additionally, the second run test showed that the factors loading and AVE ranged between .694 and .904 , which was above the desirable level of 0.50 (Bagozzi and $\mathrm{Yi}, 1991$ ). The factors' total variance explained is $65.470 \%$, and all eigenvalues are greater than one.

\subsection{Confirmatory factor analysis (CFA)}

Fig. 2 depicts the fit indices for CFA that are used to check the study instrument's measurement fit. We reached an acceptable model fit without deleting any item and obtained single factor loadings according to Anderson and Gerbing (1988) guidelines. The fit indices showed that the Chi-square divided by the degrees of Freedom $\left(\chi^{2} / \mathrm{df}\right)$ is $165.314 / 80$, goodness of fit index (GFI) is .913, the adjusted goodness of fit index (AGFI) is .869, normed fit index (NFI) is .879, comparative fit index (CFI) is .933, root mean residual is .048 and the root mean square error of approximation (RMSEA) is .068. Thus, those values are within the threshold limits and the study's measurement model is a good fit.

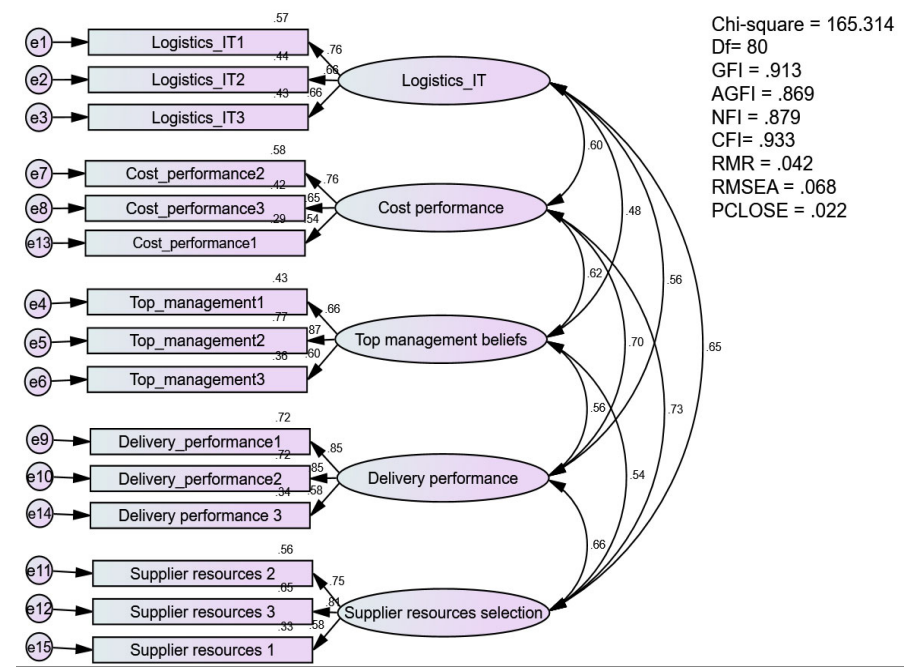

Fig. 2. Goodness of fit indices

\subsection{Reliability and validity}

The goodness of measures' reliability of the internal consistency of measurement items and their convergent and discriminant validity was checked to confirm individual reliability and validity of the measurement. Table (3) reveals the results of the measurement, in which composite reliability scores ranged between .780 and .916 , confirming an above satisfactory reliability level of 0.7 (Hair et al., 2010; Bagozzi \& Yi, 1988), showed that our distributed questionnaire sample met the internal consistency reliability standards. All the study constructs' AVE values exceed 0.5 , except one that was close to 0.5 , confirming appropriate convergent validity (Fornell \& Larcker, 1981). To ensure satisfactory discriminant validity, the inter-construct correlations should be lower than 0.85 (Kline, 2005). Further, results showed that each construct's square root of AVE, compared to their squared correlations construct, is higher. Therefore, our study measurement showed accepted discriminant validity. A variation inflation factor (VIF) was used to test multicollinearity; the results revealed that VIF values exceeded 10, which reflects the safety of our study model (Belsey et al., 1980). Table 3 provides the mean and standard deviation of the study's constructs. 
Table 2

Reliability and validity tests results and the mean and standard deviation

\begin{tabular}{cccccccccccc} 
& Mean & $\begin{array}{c}\text { Std. } \\
\text { Deviation }\end{array}$ & CR & AVE & MSV & MaxR(H) & LDP & L IT & SRS & TMBs & LCP \\
\hline LDP & 4.3506 & .77283 & 0.811 & 0.595 & 0.490 & 0.852 & 0.771 & & \\
LIT & 3.9969 & .55459 & 0.734 & 0.498 & 0.428 & 0.742 & 0.555 & 0.693 & \\
SRS & 4.0348 & .63044 & 0.757 & 0.596 & 0.539 & 0.785 & 0.662 & 0.654 & 0.717 \\
TMBs & 3.7579 & .56077 & 0.759 & 0.519 & 0.386 & 0.821 & 0.556 & 0.478 & 0.540 & 0.721 \\
LCP & 4.2030 & .63058 & 0.709 & 0.518 & 0.482 & 0.718 & 0.700 & 0.604 & 0.734 & 0.621 \\
\hline
\end{tabular}

\subsection{Structural model and hypotheses testing}

After the measurement model met the overall goodness of measurement, we used the SEM to test the hypotheses, providing a direct effect on the output file as unstandardized and standardized. Fig. 3 shows the testing results of the structural model's GFI $\chi 2=1.649, \mathrm{DF}=3, \mathrm{CMIN} / \mathrm{DF}=1.138$ with $\mathrm{RMSEA}=.000, \mathrm{NFI}=.99, \mathrm{CFI}=1.000, \mathrm{IFI}=.99, \mathrm{GFI}=.99, \mathrm{AGFI}=.98$ and $\mathrm{SRMR}=.015$, suggesting an acceptable model fit. Table 4 shows that the most hypothesized relationship paths were significantly supported under $\mathrm{t}$-statistic $=$ over 1.96 ; $\mathrm{p}$ value was less than .01 and .05 . As summarized in Table 4, SRS, TMBs, and LIT had a positive influence on LDP and LCP $(\beta=.616, p<.01, \beta=.333, p<.01$ and $\beta=.182, p<.05)$; and $(\beta$ $=.570, p<.01, \beta=.337, p<.01$; and $\beta=.139, p<.05$ ), respectively, supporting H1a, H1b, and H1c and H2a, H2b, and H2c. Moreover, the company's basic characteristics and sizes, which were used as control variables, were introduced into the regression equation. Table 4 shows that the control variables' paths significantly moderated only the relationships between (LIT, TMBs, and SRS) and LCP. $(\beta=-.040$, at $\mathrm{p}<.05)$. Therefore, H3a, H3b, and H3c were supported.

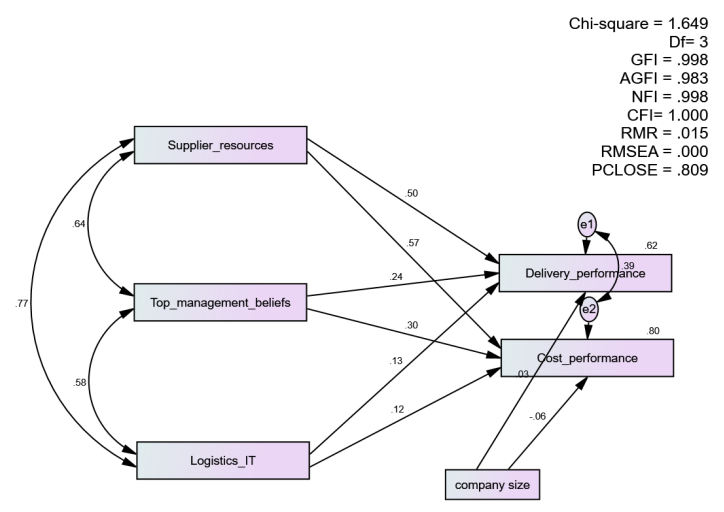

Fig. 3. Hypotheses Testing and control variable moderation

Table 3

Direct Hypotheses Testing and control variable moderation

\begin{tabular}{|c|c|c|c|c|c|c|c|}
\hline & & & Estimate & S.E. & t -statistic & $\mathbf{P}$ & Result \\
\hline LDP & $\leftarrow$ & SRS & .616 & .084 & 7.300 & $* * *$ & LDP \\
\hline LDP & $\leftarrow$ & TMBs & .333 & .074 & 4.503 & $* * *$ & Supported \\
\hline LDP & $\leftarrow$ & LIT & .182 & .091 & 2.005 & .045 & Supported \\
\hline LCP & $\leftarrow$ & SRS & .570 & .051 & 11.182 & $* * *$ & Supported \\
\hline LCP & $\leftarrow$ & TMBs & .337 & .045 & 7.560 & $* * *$ & Supported \\
\hline LCP & $\leftarrow$ & LIT & .139 & .055 & 2.539 & .011 & Supported \\
\hline LDP & $\leftarrow$ & company_size & .022 & .033 & .676 & .499 & Not moderator \\
\hline LCP & $\leftarrow$ & company_size & -.040 & .020 & -1.981 & .048 & Supported \\
\hline
\end{tabular}

\section{Discussion}

At a 0.05 level of significance, the two main hypothesized influences of LIT, TMBs, and SRS on cost and delivery performance are supported. The findings show that LIT, TMBs, and SRS can improve logistics performance of cost and delivery. Further, the company size effects on IT, TMBs, and SRS relationships with delivery performance are blurred at all moderating levels, in contrast similar relationships with cost performance. These results are consistent with the existing literature that explores better performance, for instance, top management can be regarded as a firm's key resource that affects business processes and strategies and their outcomes (Yuana et al., 2020). The positive TMBs encourage preparing valued decisions with the supply chain and stimulating the firm's to increase their commitment to conduct business processes, reduce cost, and conduct deliveries. Suppliers' management allows firms to achieve the advantages of being reactive, agile, speedy, and profitable (Doyle et al., 2006). Li et al. (2003) reported that direct supplier development has proven to be significant predictors of purchasing performance, in terms of on-time delivery and quality performance. Clark (1989) showed that intensive supplier involvement creates advantages in terms of lead times and costs in the development of projects. Squire et 
al. (2009) adopted the theory to certify that a strong relationship exists between suppliers' capabilities, supply chain collaboration and buyer performance. SRS can provide the motive that encourages other supply chain members to spend a long time searching for them, owing to their perceived prospective value in serving their customers. Most of the food and beverages firms acquire a strong LIT, may have IT climate for it, and find providers with sufficient technological capability at their market environment. Rivard et al. (2006) indicated that most RBV studies asserted that IT capability should enhance its implementation, which is affected by company size. Developments in IT international supply chain enable companies to reduce transaction costs relating to the control of goods flows and to ensure quick responses to customer orders (Boon\#itt \& Wong, 2011). Developing strong IT capabilities can improve firm performance (Ravichandran \& Lertwongsatien, 2005), and integrated IT reduces transportation costs (Farooq et al., 2019). Finally, this study's findings showed that company size moderated the relationships between LIT, TMBs, and SRS, and LCP. This is in line with the findings of many studies that have confirmed the moderating effect of firm size on the relationship between IT investments and firm performance (Dong $\&$ Yang, 2020; Fores \& Camison, 2016; Kirca et al., 2011). The size of firms governs the absolute financial performances of a business organization positively (Ali, 2020), and significantly affects earnings management (Carmel, 2005).

\subsection{Implications and contributions}

This study has several theoretical and practical implications and contributions for practicing managers. This study has concentrated principally on the application of ERBV concept by evaluating its role in firm's resources and jointly in the improvement of logistic performance among Sudanese food and beverages manufacturing firms. The first contribution is that this study provides empirical evidence that supports the proposed relationships in the research questions, which spreads the utilization of ERBV. It finds some empirical support confirming that companies that manage internal resources with the external resources better are more likely to reach higher echelons of logistic performance, compared to their competitors that do not. Thus, management should consider the significance of combining the two types of resources to improve performance outputs. Second contribution is that although the surveyed firms conduct fast delivery, reducing the logistic cost by managing SRS, LIT, and TMBs can offer solutions to solve these firm-searching problems and increase competitiveness through cost and delivery services. Third contribution is our results have implications for top management and supply chain managers in the food and beverages industry. Learning from knowledge acquired from suppliers and other key supply chain partners act as a resource that combines with internal resources for competitive advantage. Fourth contribution is that due to poor selection of suppliers' resources, manufacturing firms face the risk of delivering customers' orders in specific time and increasing performance cost. Further, benefits of supply chain parties' in managing their internal resources increase after linking these resources with other external resources to create great value for customer satisfaction and loyalty. Fifth Second contribution is that supplier resources help to decrease production cost, facilitate access to high standard of production quality, and free up some production assets like quality control. SRS plays a critical role in the flow of raw material from production to the end consumption, requiring goods that satisfy the customers' needs.

Practitioners and academics should view suppliers as a resource that shortens the length of the supply chain and minimizes transaction cost and acquire a system that identifies and ranks the available suppliers' resources, capabilities, and preferred features according to the potential benefits to firms. Currently, key suppliers' resources are perceived the same way as firms' own internal resources that are very essential to driving customers' services, coordination, and future mergers and building and fostering long-term relationships. Additionally, they lead to more inter-organizational synchronized activities, similarities, and interdependencies, such as shared corporate culture, thus facing the joint risk, supporting information sharing, and jointly exploiting market opportunities. Efforts should be made to encourage firms to select suppliers as resources. Lastly, this study contributes to the literature by researching on the previously untested hypotheses on TMB, SRS, LIT as effectual means of delivery and cost performance.

\subsection{Limitations and future studies directions}

This study has some limitations and suggests potential opportunities for future studies. First, although the study used measurement instruments from previous studies, new measuring items should be added. This study sample comprises only Sudanese food and beverages. Additionally, Sudan has its own cultural, economic, and firms' operation business environment; therefore, this study model may have different results in other countries and industries, which may make the generalizability of this study's findings and replication opportunities for future studies difficult. Second, using self-administered questionnaires for data collection may have some risks related to the participants' understanding of the questions and underestimating, or overestimating, their rating. Moreover, the data gathering stage was limited to one month, which may result in different results if the periods are longer. Third, this study only investigated the effects of single tacit resource, explicit resource, and external resource on logistic performance. Future studies may probe new determinants of logistics performance, cost reduction, and speed delivery. Lastly, this study adopts only firm size as a control variable; however, other factors such as company age and types of ownership may influence the relationships proposed in this research.

\section{Conclusion}

This study clarifies how different elements of firm's internal and external resources may interact, and how they influence delivery and logistic cost performances. It simultaneously involved two supply chain parties to research cost performance. These resources have attributes that develop sustainable competitive advantage, meeting changes in individual customers' 
requirements of goods and services in time, quantity, and sustainability. TMBs, LIT support, and fit of SRS increase the efficiency of the logistics IT used to control logistics performance costs further and enhance the economies of scale in resources. ERBV entails firms accumulating, organizing, and specializing their different resources and the strategic search for other integrated firms' resources management to boost their performance distinctiveness. The management's role in a firms' resources combination, and their capacity to acquire good resources and combine them is important for longevity.

\section{References}

Adebanjo, D., Ojadi, F., Laosirihongthong, T., \& Tickle, M. (2013). A case study of supplier selection in developing economies: A perspective on institutional theory and corporate social responsibility. Supply Chain Management: An International Journal, 18(5), 553-566.

Ali, A. (2020). Does Size Affect Financial Performance? Absolute and Relative Analysis of Materials Sector Companies of Saudi Arabia. Journal of Critical Reviews, 7(15). 212-220.

Anderson, J.C., Gerbing, D.W. (1988). Structural equation modeling in practice: a review and recommended two-step approach. Psychological bulletin, 103(3), 411-423.

Ang, S., \& Cummings, L.L. (1997). Strategic response to institutional influences on information systems outsourcing. Organization Science 8(3), 235-256.

Armstrong, J.S., \& Overton, T.S. (1977). Estimating nonresponse bias in mail surveys. Journal of Marketing Research, 14(3), 396-402.

Arya, B., \& Lin, Z. (2007). Understanding collaboration outcomes from an extended resource-based view perspective: the roles of organizational characteristics, partner attributes, and network structures. Journal of Management, 33(5), 697-723.

Bag, S., Gupta, S., \& Luo, Z. (2020). Examining the role of logistics 4.0 enabled dynamic capabilities on firm performance. International Journal of Logistics Management, 25(1), 148-164.

Bagozzi, R. P., \& Yi, Y. (1991). Multitrait-multimethod matrices in consumer research. Journal of Consumer Research, 17(4), 426-439.

Bagozzi, R.P. \& Yi, Y. (1988). On the evaluation for structural equation models. Journal of the Academy of Marketing Science, 16(1), 74-94.

Barney, J. B. (2001). Is the resource-based view a useful perspective for strategic management research? Yes. Academy of Management Review, 26(1), 41-57.

Belsey, D. A., Kuh, E., \& Welsch, R. E. (1980). Regression diagnostics: Identifying influential data and sources of collinearity. New York: John Wiley.

Benjamin, R. I., Rockart, J. F., Michael, S., Morton, S., Wyman, J., Times, C., ... \& Baysinger, B. D. (1984). Information Technology: A Strategic Opportunity. Sloan Management Review, 25(3), 3-10.

Benjamin, T.H., \& Terry, A.B., (2012). Toward creating competitive advantage with logistics information technology. International Journal of Physical Distribution \& Logistics Management, 42(1), 8-35.

Bhutta, K.S., \& Huq, F. (2002). Supplier selection problem: a comparison of the total cost of ownership and analytic hierarchy process approaches. Supply Chain Management: An International Journal, 7(3), 126-135.

Boon-itt, S., \& Wong, C. Y. (2011). The moderating effects of technological and demand uncertainties on the relationship between supply chain integration and customer delivery performance. International Journal of Physical Distribution \& Logistics Management, 41(3), 253-276.

Buonanno, G., Faverio, P., Pigni, F., Ravarini, A., Sciuto, D. and Tagliavini, M. (2005). Factors affecting ERP system adoption: a comparative analysis between SMEs and large companies. Journal of Enterprise Information Management, $18(4), 384-426$.

Carmel, J. (2005). Effect of Profit Management on Manufacturing Disclosure Levels included in the LQ-45 Index. National Symposium on Accounting 8 Solo.

Castro, J.A.O., \& Jaimes, W.A. (2017). Dynamic Impact of the Structure of the Supply Chain of Perishable Foods on Logistics Performance and Food Security. Journal of Industrial Engineering and Management, 10(4), 687-710.

Chenhall, R.H. (2003). Management control systems design within its organizational context: Findings from contingencybased research and directions for the future. Accounting, Organizations and Society 28(2-3), 127-168.

Cheung, M.S., Myers, M.B., \& Mentzer, J.T. (2010). Does relationship learning lead to relationship value? A crossnational supply chain investigation. Journal of Operations Management, 28(6), 472-487.

Clark, K. B. (1989). Project scope and project performance: The effect of parts strategy and supplier involvement on product development. Management Science, 35(10), 1247-1263.

Clemons, E. K. (1986). Information Systems for Sustainable Competitive Advantage. Information \& Management, 11(3), 131-136.

Choy, K.L., Lee, W.B., \& Lo, V. (2003). Design of an intelligent supplier relationship management system: a hybrid case based neural network approach. Expert Systems with Applications, 24, 225-237.

Collins, J. D., Uhlenbruck, K., \& Rodriguez, P. (2008). Why firms engage in corruption: A top management perspective. Journal of Business Ethics, 87(1), 89-108.

Dai, J., Montabon, F.L., \& Cantor, D.E. (2014). Linking rival and stakeholder pressure to green supply management: mediating role of top management support. Transportation Research Part E: Logistics and Transportation Review, 71, $173-187$. 
Dong, J.Q., \& Yang, C.-H. (2020). Business value of big data analytics: a systems-theoretic approach and empirical test. Information \& Management, 57(1), 103-124.

Doering, T., De Jong, J., \& Suresh, N. (2019). Performance effects of supply chain integration: The relative impacts of two competing national culture frameworks. Cogent Business \& Management, 6(1), 1610213.

Doyle, S.A., Moore, C.M., \& Morgan, L. (2006). Supplier management in fast moving fashion retailing. Journal of Fashion Marketing and Management, 10(3), 272-281.

Duong, H.T., \& Paché, G. (2016). How informational integration can improve the relationship between buyer and supplier of logistical services: empirical evidence from Vietnam. Journal of Applied Business Research, 32(1), 341-354.

Eisenhardt, K.M., \& Martin, J.A. (2000). Dynamic capabilities: what are they? Strategic Management Journal, 21(10/11), 1105-1121.

Fang, F., Parameswaran, M., Zhao, X., \& Whinston, A. B. (2014). An economic mechanism to manage operational security risks for interorganizational information systems. Information Systems Frontiers, 16(3), 399-416.

Farooq, Q., Fu, P., Hao, Y., Jonathan, T., \& Zhang, Y. (2019). A review of management and importance of E-commerce implementation in service delivery of private express enterprises of China. SAGE Open, 9(1), 2158244018824194.

Fawcett, S.E., \& Magnan, G.M. (2004).Ten guiding principles for high-impact SCM. Business Horizons, 47(5), 67-74.

Flynn, B.B., Huo, B., \& Zhao, X. (2010). The impact of supply chain integration on performance: a contingency and configuration approach. Journal of Operations Management, 28(1), 58-71.

Fores, B., \& Camison, C. (2016). Does incremental and radical innovation performance depend on different types of knowledge accumulation capabilities and organizational size? Journal of Business Research, 69(2), 831-848.

Fornell, C., \& Larcker, D.F., (1981). Structural equation models with unobservable variables and measurement error: algebra and statistics. Journal of Marketing Research, 18(3), 382-388.

Gadde, L., \& Snehota, I. (2000). Making the most of supplier relationships. Industrial Marketing Management, 29(4), 305306.

Gaskin, J. (2012). Structural Equation Modelling in AMOS. YouTube Videos: Gaskinations.

Gimenez, C., \& Tachizawa, E.M. (2012). Extending sustainability to suppliers: a systematic literature review. Supply Chain Management: An International Journal, 17(5), 531-543.

Gopalakrishna-Remani, V., Jones, R. P., \& Camp, K. M. (2019). Levels of EMR adoption in US hospitals: An empirical examination of absorptive capacity, institutional pressures, top management beliefs, and participation. Information Systems Frontiers, 21(6), 1325-1344.

Green, K.W., Whitten, D., \& Inman, R.A. (2008). The impact of logistics performance on organizational performance in a supply chain context. Supply Chain Management: An International Journal, 13(4), 317-327.

Grimm, J.H., Hofstetter, J.S., \& Sarkis, J. (2014). Critical factors for sub-supplier management: a sustainable food supply chains perspective. International Journal of Production Economics, 152, 159-173.

Ha, S. H., \& Krishnan, R. (2008). A hybrid approach to supplier selection for the maintenance of a competitive supply chain. Expert Systems with Applications, 34(2), 1303-1311.

Hair, J. F., Black, W. C., Babin, B. J., Anderson, R. E. \& Tatham, R. L. (2006). Multivariate Data Analysis. New Jersey: Prentice Hall.

Hair, J.F., Black, W.C., Babin, B.J., \& Anderson, R.E. (2010). Multivariate Data Analysis, $7^{\text {th }}$ ed., Prentice Hall, Upper Saddle River, NJ.

Hambrick, D. C., \& Finkelstein, S. (1987). Managerial discretion: A bridge between polar views of organizational outcomes. Research in organizational behavior, 9, 369-406.

Hambrick, D. C. (2007). Upper echelons theory: An update. Academy of Management Review, 32(2), 334-343.

Han, H.-S., Lee, J.-N., Seo, Y.-W. (2008). Analyzing the impact of a firm's capability on outsourcing success: a process perspective. Information \& Management, 45(1), 31-42.

Hsiao, H., Kemp, R.G., Van der Vorst, J., \& Omta, S.O. (2010). A classification of logistic outsourcing levels and their impact on service performance: evidence from the food processing industry. International Journal of Production Economics, 124(1), 75-86.

Huo, B., Selen, W., Yan, Y., Jeff, H., \& Zhao, X. (2008). Understanding drivers of performance in the 3PL industry in Hong Kong. International Journal of Operations \& Production Management, 28(8), 722-800.

Jabbour, A.B.L., \& Jabbour, C.J. (2009). Are supplier selection criteria going green? Case studies of companies in Brazil. Industrial Management \& Data Systems, 109(4), 477-495.

Jia, F., \& Lamming, R. (2013). Cultural adaptation in Chinese-Western supply chain partnerships. International Journal of Operations \& Production Management, 33(5), 528-561.

Kenny, D. A., \& McCoach, D. B. (2003). Effect of the number of variables on measures of fit in structural equation modeling. Structural Equation Modeling, 10(3), 333-351.

Kirca, A.H., Hult, G.T.M., Roth, K., Cavusgil, S.T., Perryy, M.Z., Akdeniz, M.B., Deligonul, S.Z., Mena, J.A., Pollitte, W.A., Hoppner, J.J., Miller, J.C., White, R.C., (2011). Firm-specific assets, multinationality, and financial performance: a metaanalytic review and theoretical integration. Academy of Management Journal. 54(1), 47-72.

Kritchanchai, D., Hoeur, S., \& Engelseth, P. (2018, January). Develop a strategy for improving healthcare logistics performance. In Supply Chain Forum: An International Journal (Vol. 19, No. 1, pp. 55-69). Taylor \& Francis.

Kline, R. B. (2005). Principles and practice of structural equation modeling. $2^{\text {nd }}$ ed. New York: The Guilford Press. 
Lages, C. R., Piercy, N. F., Malhotra, N., \& Simões, C. (2020). Understanding the mechanisms of the relationship between shared values and service delivery performance of frontline employees. The International Journal of Human Resource Management, 31(21), 2737-2760.

Lai, V. S., Lai, F., \& Lowry, P. B. (2016). Technology evaluation and imitation: Do they have diferential or dichotomous efects on ERP adoption and assimilation in China? Journal of Management Information Systems, 33(4), $1209-1251$.

Lambert, D. M., \& Schwieterman, M. A. (2012). Supplier relationship management as a macro business process. Supply Chain Management: An International Journal, 17(3), 337-352.

Lavie, D. (2006). The competitive advantage of interconnected firms: an extension of the resource-based view. Academy of Management Review, 31(3), 638-658.

Lee, J., Elbashir, M.Z., Mahama, H., \& Sutton, S.G. (2014). Enablers of top management team support for integrated management control systems innovations. International Journal of Accounting Information System, 15(1), 1-25.

Lee, H. Y., Seo, Y. J., \& Dinwoodie, J. (2016). Supply chain integration and logistics performance: the role of supply chain dynamism. The International Journal of Logistics Management, 27(3), 668-685.

Li, L., Humphreys, P., Chan, L.Y., \& Kumaraswamy, M. (2003). Predicting purchasing performance: the role of supplier development programs. Journal of Material Processing Technology, 66(3/4), 1-7.

Li, S., Ragu-Nathan, B., Ragu-Nathan, T.S. \& Subba Rao, S. (2006). The Impact of Supply Chain Management Practise on Competitive Advantage and Organizational Performance. Omega, 34(1), 107 - 124.

Li, W., Liu, K., Belitski, M., Ghobadian, A., \& O’Regan, N. (2016). E-Leadership through strategic alignment: an empirical study of small- and medium-sized enterprises in the digital age. Journal of Information Technology, 31(2), $185-206$.

Liang, H. G., Saraf, N., Hu, Q., \& Xue, Y. J. (2007). Assimilation of enterprise systems: The effect of institutional pressures and the mediating role of top management. Management Information System Quarterly, 31(1), 59-87.

Liao, Y., Hong, P., \& Rao, S.S. (2010). Supply chain management, supply flexibility and performance outcomes: an empirical investigation of manufacturing firms. Journal of Supply Chain Management, 46(3), 6-22.

Mathews, J. A. (2003). Competitive dynamics and economic learning: an extended resource-based view. Industrial and Corporate Change, 12(1), 115-145.

Masudin, I., Fernanda, F.W., \& Widayat, W. (2018). Halal Logistics Performance and Customer Loyalty: From the Literature Review to a Conceptual Framework. International Journal of Technology, 9(5), 1072-1084.

McFarland, F. W. (1984). Information Technology Changes the Way You Compete. Harvard Business Review, 62(3), 98103.

Mettler, T., \& Rohner, P. (2009). Supplier relationship management: a case study in the context of health care. Journal of Theoretical and Applied Electronic Commerce Research, 4(3), 58-71.

Michaelis, B., Kunze, F., \& Bruch, H. (2015). New insights on CEO charisma attribution in companies of different sizes and ownership structure: the role of prior company performance. Journal of Business Economics, 85(7), 793-815.

Min, S., \& Mentzer, J. T. (2004). Developing and measuring supply chain management concepts. Journal of Business Logistics, 25(1), 63-99.

Miranda, S.M., \& Kim, Y.M. (2006). Professional versus political contexts: institutional mitigation and the transaction cost heuristic in information systems outsourcing. Management Information System Quarterly, 30(3), 725-753.

Mitrega, M., Forkmann, S., Ramos, C., \& Henneberg, S. C. (2012). Networking capability in business relationships — Concept and scale development. Industrial Marketing Management, 41(5), 739-751.

Müller, J. M., Kiel, D., \& Voigt, K. I. (2018). What drives the implementation of Industry 4.0? The role of opportunities and challenges in the context of sustainability. Sustainability, 10(1), 247.

Oliveira, T., \& Martins, M.F. (2011). Literature Review of Information Technology Adoption Models at Firm Level. The Electronic Journal of Information Systems Evaluation, 14(1), 110-121.

Ordoobadi, S. M. (2009). Development of a supplier selection model using fuzzy logic. Supply Chain Management: An International Journal, 14(4), 314-327.

Ouafae, P.Z.O., \& Laila, Z. (2019). Determinants of logistics performance: a case study of the retail sector. 2019 International Colloquium on Logistics and Supply Chain Management (LOGISTIQUA), 2019, pp. 1-5, doi: 10.1109/LOGISTIQUA.2019.8907259.

Park, J., Shin, K., Chang, T. W., \& Park, J. (2010). An integrative framework for supplier relationship management. Industrial Management \& Data Systems, 110(4), 495-515.

Podsakoff, P.M., Mackenzie, S.B., Lee, J.Y., \& Podsakoff, N.P. (2003). Common method biases in behavioral research: a critical review of the literature and recommended remedies. Journal of Applied Psychology, 88(5), 879-903.

Porter, M. (1985). Competitive Advantage. New York: Free Press.

Raguseo, E., Vitari, C., \& Pigni, F. (2020). Profiting from big data analytics: The moderating roles of industry concentration and firm size. International Journal of Production Economics, 229, 107758.

Ravichandran, T., \& Lertwongsatien, C. (2005). Effect of information systems resources and capabilities on firm performance: A resource-based perspective. Journal of Management Information Systems, 21(4), 237-276.

Reuer, J.J., \& Koza, M.P. (2000). On lemons and indigestibility: Resource assembly through joint ventures. Strategic Management Journal, 21(2), 195-197.

Richey, R.G., Chen, H., Upreti, R., Fawcett, S.E., \& Adams, F.G. (2009). The moderating role of barriers on the relationship between drivers to supply chain integration and firm performance. International Journal of Physical Distribution \& Logistics Management, 39(10), 826-840. 
Rosenzweig, E.D., Roth, A.V., \& Dean, J.W. Jr (2003). The influence of an integration strategy on competitive capabilities and business performance: an exploratory study of consumer products manufacturers. Journal of Operations Management, 21(4), 437-56.

Rivard, S., Raymond, L., \& Verreault, D. (2006). Resource-based view and competitive strategy: an integrated model of the contribution of information technology to firm performance. Journal of Strategic Information Systems 15(1), 29-50.

Shrivastava, P. (1983). A typology of organizational learning systems. Journal of Management Studies, 20(1), 7-28.

Singh, P., \& Power, D. (2009). The nature and effectiveness of collaboration between firms, their customers and suppliers: a supply chain perspective. Supply Chain Management: An International Journal, 14(3), 189-200.

Sirmon, D.G., Hitt, M.A., \& Ireland, R.D. (2007). Managing firm resources in dynamic environments to create value: looking inside the black box. Academy of Management Review, 32(1), 273-292.

Son, I., Lee, D., Lee, J.-N., \& Chang, Y.B. (2014). Market perception on cloud computing initiatives in organizations: An extended resource-based view. Information and Management, 51(6), 653-669.

Squire, B., Cousins, P.D., Lawson, B. and Brown, S. (2009). The effect of supplier manufacturing capabilities on buyer responsiveness. International Journal of Operations \& Production Management, 29(8), 766-788.

Stewart, G. (1995). Supply Chain Performance Benchmarking Study Reveals Keys to Supply Chain Excellence. Logistics Information Management, 8(2), 38-44.

Takacs, B., \& Borrion, A. (2020). The use of life cycle-based approaches in the food service sector to improve sustainability: A systematic review. Sustainability, 12(9), 3504.

Ting, S.C., \& Cho, D.I. (2008). An integrated approach for supplier selection and purchasing decisions. Supply Chain Management: An International Journal, 13(2), 116-127.

Tuo, G., Feng, Y., \& Sarpong, S. (2019). A configurational model of reward-based crowdfunding project characteristics and operational approaches to delivery performance. Decision Support Systems, 120, 60-71.

Ulaga, W., \& Eggert, A. (2006). Value-based differentiation in business relationships: Gaining and sustaining key supplier status. Journal of Marketing, 70(1), 119-136.

Van Weele, A. J. (2009). Purchasing and supply chain management: Analysis, strategy, planning and practice. $5^{\text {th }}$ ed., Cengage Learning EMEA, Hampshire.

Vinholis, M. D., de Souza Filho, H. M., Carrer, M. J., \& Chaddad, F. R. (2014). Transaction attributes and adoption of hybrid governance in the Brazilian cattle market. Embrapa Pecuária Sudeste-Artigo em periódico indexado (ALICE). Journal on Chain and Network Science, 14(3), 189-199.

Villena, V. H., Gomez-Mejia, L. R., \& Revilla, E. (2009). The decision of the supply chain executive to support or impede supply chain integration: A multidisciplinary behavioral agency perspective. Decision Sciences, 40(4), 635-665.

Vonderembse, M. A., \& Tracey, M. (1999). The impact of supplier selection criteria and supplier involvement on manufacturing performance. Journal of Supply Chain Management. 35(3), 33-39.

Warnier, V., Weppe, X., \& Lecocq, X. (2013). Extending resource-based theory: considering strategic, ordinary and junk resources. Management Decision, 51(7), 1359-1379.

Wade, M., \& Hulland, J. (2004). Review: The resource-based view and information systems research: Review, extension, and suggestions for future research. Management Information Systems Quarterly, 28(1), 107-142.

Wei, S., Ke, W., Lado, A. A., Liu, H., \& Wei, K. K. (2020). The effects of justice and top management beliefs and participation: an exploratory study in the context of digital supply chain management. Journal of Business Ethics, 166(1), 51-71.

Winkelhaus, S., \& Grosse, E.H. (2020). Logistics 4.0: a systematic review towards a new logistics system. International Journal of Production Research, 58(1), 18-43.

Wiseman, Charles (1985). Strategic Vision. Computerworld, 20, 1-17.

Wisner, D. (2003). Structural equation model of supply chain management strategies and firm performance. Journal of Business Logistics, 24(1), 1-26.

Xu, D., Huo, B., \& Sun, L. (2014). Relationships between intra-organizational resources, supply chain integration and business performance. Industrial Management \& Data Systems, 114(8), 1186-1206.

Yang, Y., Jia, F., \& Xu, Z. (2019). Towards an integrated conceptual model of supply chain learning: an extended resourcebased view. Supply Chain Management: An International Journal, 24(2), 189-214.

Yuan, Y., Chu, Z., Lai, F., \& Wu, H. (2020). The impact of transaction attributes on logistics outsourcing success: A moderated mediation model. International Journal of Production Economics, 219, 54-65.

Yang, C. G., \& Lee, H. J. (2016). A study on the antecedents of health care information protection intention. Information Systems Frontiers, 18(2), 253-263.

Zhao, M., Dröge, C., \& Stank, T.P. (2001). The effects of logistics capabilities on firm performance: customer-focused versus information-focused capabilities. Journal of Business Logistics. 22(2), 91-107.

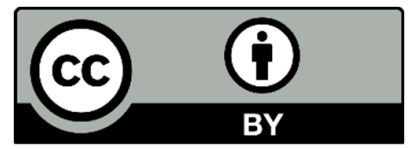

(C) 2021 by the authors; licensee Growing Science, Canada. This is an open access article distributed under the terms and conditions of the Creative Commons Attribution (CCBY) license (http://creativecommons.org/licenses/by/4.0/). 